\title{
The Effect of Compensation on Ships Crew Performance of Floating Crane Ratu Giok-2 (Case Study at PT. Kartika Samudra Adijaya)
}

\author{
L Barasa $^{1}$, B Sumali ${ }^{2}$, P Nancy $^{3}$, Cardiana $^{4}$ \\ \{larsenbarasa@gmail.com ${ }^{1}$, bambs511@gmail.com ${ }^{2}$, cardianabebos20@gmail.com³ \\ nancy.lumbanbatu@gmail.com $\left.{ }^{4}\right\}$
}

STIP Jakarta, Indonesia ${ }^{1,2,3,4}$

\begin{abstract}
Crew of the ship is a very important component in supporting the ship operations of shipping company. Bad performance can prevent companies for reaching their objectives. In the process of work, ship's crew get compensation contains direct compensation and indirect compensation. The Purpose of this research is to analyze how much the effect of compensation on ship crew performance of FC. Ratu Giok-2 with data analysis techniques using Simple Linear Regression Methode. Period of this research is from August 2016 until July 2017. Independent varaible is compensation and dependent variable is ships crew performance. Population as well as sample is 32 respondents who are ships crew of FC. Ratu Giok-2, data obtained through questionnaries and process with SPSS program. Based on analysis of determinant coefficient get $57 \%$. This is indicate that percentage of compensation variable contribution to ship crew performance variable is $57 \%$, the other $43 \%$ is effected by other variable ouside the research such as training, competence, motivation, and etc. Its mean that compensation variable has a positive and significant effect on ships crew performance. Based on the calculation of average score of each indikator on compensation variable through questionnaries, the lowest score is basic salary indicator. This is indicate that ships crew feels that the basic salary which they got from company not fulfill their needs. Then the lowest score in ships crew performance variable is efficient work indicator. Its show that ships crew feels that they haven't work quickly, accurately, and safely.
\end{abstract}

Keywords: Direct Compensation, Indirect Compensation, and Ships Crew Performance

\section{Introduction}

PT. Kartika Samudra Adijaya (KSA) is an Indonesian barging company that provides efficient and competitive logistics services for the Indonesian and international coal industries, since its establishment in 1994 the company has supported the growth of the Indonesian coal industry, as well as developing its business as a shipping company in the shipping sector with its vessels such as tugboat, barge, and floating crane (crane barge). PT. KSA has 4 Floating 
Crane units namely FC. RatuGiok operates in Merak, FC. Ratu Giok-2 which operates in Samarinda, as well as FC. Ratu Giok-3 and FC. Ratu Giok-5 which operates in Banjarmasin.

Ships crew that operates a floating crane consists of 25 people, namely, Master, Chief Engineer, Chief Officer, Second Officer, Electrician, Boatswain, Able Seamen, Oiler, Mechanic, Chief Cook, Messboy, Crane Operator, and Dozer Operator. The role of Ship Crew has a very important and strategic position in a shipping company to reach its destination. But in reality the ship crew in carrying out their duties do not carry out work discipline properly, the crew of the ship when they are on leave, which must return from the 1st leave every month, 5 of the 10 crew members leave the ship on the 3rd to 5th of each month. Then the competence of the ship's crew is low, when making a monthly cargo report, the company has determined that the report must be sent on the 1st of each month, but the ship's crew sends the report on the 4th to the 5th. ships do not install expired labels on work safety devices such as liferaftt, lifebouy, and fire extinguisher, even though the company has given instructions to put labels on work safety equipment to make it easier to check.

Compensation is a reward received by the ship's crew for services that have operated the company's ship. Compensation received by ship crew in the form of basic salary stated in the sea labor agreement, allowances, incentives, overtime wages and health insurance. But in reality PT. KSA provides compensation to the crew of the ship is not appropriate when compared with the UMR (Upah Minimum Regional or regional minimum wage) city of Samarinda. salary received by the crew of the ship with the messboy position which is equal to IDR 2,000,000 consisting of IDR 1,752,500 for basic salary, IDR 150,000 for overtime wages, IDR 97,500 for incentives. Whereas the UMR in Samarinda city is IDR 2,400,000, which means that the compensation received by the crew is below the UMR in Samarinda.

Ship crew performance is a very important thing in the business of a shipping company to achieve its objectives. Output of crew crew performance for deck department is to regulate the ongoing loading / unloading activities and keep cargo from the origin port until arriving at the destination port. Regulate the supply of fresh water on boats for bathing purposes and others. Adjusting the direction of navigation to arrive at the destination port on time and the safety of the entire crew of the ship is maintained. Create a cruise map route. Regulate, examine and maintain all ship safety equipment so that when an emergency occurs, the safety device can be used and function properly. Output of the engine's engine performance is responsible for all the engines on board, both the main engine, auxiliary engine, steering engine, crane engine, pumping machine, and the anchor engine. But in reality the performance of the ship's crew decreased, some of them did not comply with work safety procedures, the ship crew did not use work safety equipment when outdoors or in the engine room. 10 of the $25 \mathrm{crew}$ members did not use Google's safety helmet and safety.

Based on the phenomenon that occurs above, the author is interested in knowing more about how much "The Effect Of Compensation On Ships Crew Performance Floating Crane (FC) Ratu Giok-2 (Case study at PT. KartikaSamudraAdijaya)"

Based on the description above, the problems faced and need to be examined are:

How big is the effect of compensation on ships crew performance Floating Crane (FC) Ratu Giok-2? 


\section{Literature Review}

\subsection{Compensation}

Compensation is one of the important functions in human resource management (HRM). According to Edy Sutrisno [1], in his book entitled "Human Resource Management", compensation is one of the most sensitive aspects in work relations. Cases that occur in work relationships contain compensation problems and various related aspects such as benefits, compensation increases, compensation structures, and compensation scales.

According to Panggabean quoted by EdySutrisno (2009: 197), compensation can be defined as any form of award given to employees as a reward for the contributions they give to the organization.

Furthermore, according to Singodimejo quoted by EdySutrisno [1], compensation is all remuneration received by an employee from his company as a result of the services / energy he has given to the company.

Furthermore, according to Malayan S.P Hasibuan [2], in his book entitled "Human Resource Management", compensation is all income in the form of money, goods directly or indirectly received by employees in return for services provided to companies. Compensation in the form of money means that compensation is paid in the amount of currency to the employee concerned.

Compensation in the form of goods means that compensation is paid for with goods, for example compensation is paid $10 \%$ of the production produced. According to William B. Werther and Keith Davis quoted by Malays S. P Hasibuan [2], compensation is what a worker receives in return for the work he is given. Both periodic wages or salary are periodically designed and managed by the personnel department.

The next theory put forward by T. Hani Handoko [3], in the title of his book "Personnel Management and Human Resources", Compensation is everything that employees receive as a reward for their work.

Based on the description above, it can be synthesized that compensation is an award / reward to workers who have contributed in realizing its goals, through activities called work consisting of dimensions: 1) direct compensation, with indicators: (a) basic salary, (b) bonus, (c) overtime wages, (d) incentives; 2) indirect compensation, with indicators: (a) leave allowance, (b) promotion, (c) transport money, (d) meal allowance, (e) insurance, (f) scholarship.

\subsection{Ships Crew Performance}

Hadari Nawawi [4], in his book entitled "evaluation and management of performance in the company and industry environment", suggests that the implementation of business strategies and results (out come) that can be achieved in conducting business to achieve operational goals and ideal goals / objectives strategic organization / company is very dependent on performance and how the performance is managed / managed (performance management). For this reason, it is necessary to clarify in advance the definition of performance as described below.

Furthermore, according to Judith R Gordon, quoted by Hadari Nawawi [4], performance is a function of the ability of workers to accept the purpose of work, the level of achievement of goals and the interaction between goals and the ability ofworkers.

Next, according to SuyadiPrawirosentono, quoted by Hadari Nawawi [4], performance is the result of work achieved by a person or group of people in an organization / company in accordance with their respective authorities and responsibilities, in order to achieve organizational goals legally, not violate law and in accordance with morals and ethics. 
The next theory according to Mr. Payaman J Simanjuntak [5], in his book entitled "Management and performance evaluation", performance is the level of achievement of results for the implementation of certain tasks. Company performance is the level of achievement of results in order to realize company goals. Performance management is the whole activity carried out to improve the performance of the company / organization, including the performance of each individual and working group in the company.

The 1992 constitution No. 21 concerning shipping states that a crew is a person who works or is employed on a ship by the owner or operator of the ship to carry out duties on board according to the position stated in the certificate book, including the Captain.

Captain is a crew on the vessel who becomes the Master and have an authority and responsibility in accordance with the applicable constitutions and regulations. Captain/Master is the person who leads the ship (34th provision of Trade Law/KUHD).

Based on the description above, it can be synthesized that the crew's performance describes what is done by a crew on board in carrying out its main tasks, measured through dimensions: 1) work methods, with indicators: (a) quantity of work, (b) accuracy time, (c) effective work, and (d) efficient work; 2) work results, with indicators: (a) quality of work, (b) success of work, and (c) according to work standards; 3 ) work attitude, with indicators: (a) accuracy and patience, (b) responsibility, and (c) problem solving.

\section{Method}

\subsection{Research Sites}

This research was conducted at PT. KartikaSamudraAdijaya which is located in Samarinda, East Kalimantan for 12 months starting August 2016 until August 2017. PT. KartikaSamudraAdijaya is a shipping company engaged in the Tug and Barge field which has a fleet of Tugboat, Barge and Floating Crane vessels.

\subsection{Population and Samples}

The population in a study is a set of objects that can be used as research sources in the form of objects, humans or events that occur as objects or targets of research. According to $\mathrm{Mr}$ Arikunto (2005), the population isthe whole of the object research. According to Sugiyono (2005), the sample is part of the population that is the source of research, which is part of the population that is the source of data in research, which is part of the number of characteristics possessed by the population.

The population in this research were all 32 crew members of the Floating Crane Ratu Giok$2 \mathrm{crew}$. Therefore this research directly assesses the population without being sampled first.

\subsection{Data Analysis Technique}

1. Validity Test

2. Reliability Test

3. Analysis of the Correlation Coefficient

4. Analysis of Simple Linear Regression

5. Analysis of Determining Coefficients

6. Calculation of the average score of each indicator on each variable 


\section{Result and Discussion}

\begin{tabular}{|c|c|c|c|c|c|c|c|}
\hline \multirow{2}{*}{ No } & \multirow{2}{*}{ Variable Compensation (X) } & \multicolumn{5}{|c|}{ Respondent's answer } & \multirow{2}{*}{ Total } \\
\hline & & SS & $\mathrm{S}$ & RG & TS & STS & \\
\hline 1 & $\begin{array}{l}\text { The basic salary provided is } \\
\text { sufficient for your needs. }\end{array}$ & 1 & 14 & 14 & 3 & 0 & 32 \\
\hline 2 & $\begin{array}{l}\text { Bonuses are given as long as the } \\
\text { crew is on board. }\end{array}$ & 7 & 18 & 7 & 0 & 0 & 32 \\
\hline 3 & $\begin{array}{l}\text { Work experience affects the size } \\
\text { of overtime wages. }\end{array}$ & 6 & 22 & 4 & 0 & 0 & 32 \\
\hline 4 & $\begin{array}{l}\text { The diploma level affects the } \\
\text { amount of incentives. }\end{array}$ & 8 & 13 & 11 & 0 & 0 & 32 \\
\hline 5 & $\begin{array}{l}\text { The leave allowance provided is } \\
\text { sufficient for your needs. }\end{array}$ & 12 & 16 & 4 & 0 & 0 & 32 \\
\hline 6 & $\begin{array}{l}\text { You get a promotion from the } \\
\text { company. }\end{array}$ & 8 & 16 & 6 & 2 & 0 & 32 \\
\hline 7 & $\begin{array}{l}\text { Transport money from the } \\
\text { company is sufficient for your } \\
\text { trip. }\end{array}$ & 10 & 17 & 4 & 1 & 0 & 32 \\
\hline 8 & $\begin{array}{l}\text { The food provided is sufficient } \\
\text { for your food needs. }\end{array}$ & 8 & 10 & 12 & 2 & 0 & 32 \\
\hline 9 & $\begin{array}{l}\text { You are satisfied with the } \\
\text { insurance provided by the } \\
\text { company. }\end{array}$ & 7 & 16 & 9 & 0 & 0 & 32 \\
\hline 10 & $\begin{array}{l}\text { There are scholarships from } \\
\text { companies to continue their } \\
\text { education. }\end{array}$ & 10 & 19 & 2 & 1 & 0 & 32 \\
\hline & Total & 77 & 161 & 73 & 9 & 0 & 320 \\
\hline & Persentation & 24 & 50 & 23 & 3 & 0 & 100 \\
\hline
\end{tabular}

Respondent's Response to Variable Compensation (X)

\begin{tabular}{cccccc}
\hline Item & Scale & Frequency & score & Mean & Category \\
\hline The basic & SS & 1 & 5 & & \\
salary provided & S & 14 & 56 & & Pretty good \\
is sufficient for & RG & 14 & 42 & 3,4 & \\
your needs. & TS & 3 & 6 & & \\
& STS & - & & & \\
& & & & & \\
\hline total & & 32 & 109 & & \\
\hline
\end{tabular}

Table 4.2: Indicators of Basic Salaries 


\begin{tabular}{|c|c|c|c|c|c|}
\hline Item & Scale & Frequency & Score & Mean & Category \\
\hline Bonuses are & SS & 7 & 35 & & \\
\hline given as long & $\mathrm{S}$ & 18 & 72 & & \\
\hline as the crew is & $\mathrm{RG}$ & 7 & 21 & 4 & good \\
\hline on board. & $\mathrm{TS}$ & - & & & \\
\hline & STS & - & & & \\
\hline Total & & 32 & 128 & & \\
\hline \multicolumn{6}{|c|}{ Tabel 4.3: Bonus indicator } \\
\hline Item & Scale & Frequency & Score & mean & Category \\
\hline Work & SS & 6 & 30 & & \\
\hline experience & S & 22 & 88 & & \\
\hline affect the size & RG & 4 & 12 & 4.06 & Well \\
\hline of overtime & $\mathrm{TS}$ & - & & & \\
\hline wages. & STS & - & & & \\
\hline Total & & 32 & 130 & & \\
\hline
\end{tabular}

Table 4.4: Indicators Overtime Wages

\begin{tabular}{cccccc}
\hline Item & Scale & Frequency & Score & mean & Category \\
\hline Diploma level & SS & 8 & 40 & & \\
affects the & S & 13 & 52 & & \\
amount of & RG & 11 & 33 & 3.9 & Well \\
incentive. & TS & - & & & \\
& STS & - & & \\
& & 32 & 125 & & \\
\hline total & & & & \\
\hline
\end{tabular}

Table 4.5: Indicators incentives

\begin{tabular}{cccccc}
\hline item & Scale & Frequency & Score & mean & Category \\
\hline Leave benefits & SS & 12 & 60 & & \\
provided meet & S & 16 & 64 & & \\
your needs. & RG & 4 & 12 & 4.25 & Very good \\
& TS & - & & & \\
& STS & - & & & \\
& & & & & \\
\hline total & & 32 & 136 & & \\
\hline
\end{tabular}

Table 4.6: Indicators Leave Benefits 


\begin{tabular}{cccccc}
\hline item & Scale & Frequency & Score & mean & Category \\
\hline You get a & SS & 8 & 40 & & \\
promotion of & S & 16 & 64 & & \\
the company. & RG & 6 & 18 & 3.8 & Well \\
& TS & - & & & \\
& STS & - & & & \\
\hline Total & & 32 & 122 & &
\end{tabular}

Table 4.7: Indicators Promotion Position

\begin{tabular}{cccccc}
\hline Item & Scale & Frequency & Score & Mean & Category \\
\hline The Money & SS & 10 & 50 & & \\
Transport from & S & 17 & 68 & & \\
the company is & RG & 4 & 12 & 4,12 & Good \\
enough for & TS & 1 & 2 & & \\
your trip & STS & - & & & \\
& & & & & \\
\hline Total & & 32 & 132 & & \\
\hline
\end{tabular}

Table 4.8: Transport Money Indicator

\begin{tabular}{cccccc}
\hline Item & Scale & Frequency & Score & Mean & Category \\
\hline The food & SS & 8 & 40 & & \\
provided is & S & 10 & 40 & & \\
enough for & RG & 12 & 36 & 3,75 & Good \\
your food & TS & 2 & 4 & & \\
needs. & STS & - & & & \\
& & & & \\
\hline Total & & 32 & 120 & \\
\hline
\end{tabular}

Table 4.9: Food Money Indicator

\begin{tabular}{cccccc}
\hline Item & Scale & Frequency & Score & Mean & Category \\
\hline You are & SS & 7 & 35 & & \\
satisfied with & S & 16 & 64 & & \\
the insurance & RG & 9 & 27 & 3,9 & Good \\
provided by the & TS & - & & & \\
company. & STS & - & & & \\
& & & & & \\
\hline Total & & 32 & 126 & &
\end{tabular}

Tabel 4.10: Insurance Indicator 


\begin{tabular}{cccccc}
\hline Item & Scale & Frequency & Score & Mean & categori \\
\hline A scholarship & SS & 10 & 50 & & \\
from the & S & 19 & 76 & & \\
company to & RG & 2 & 6 & 4,1 & Very good \\
continue the & TS & 1 & 2 & & \\
study program & STS & - & & & \\
& & & & & \\
\hline Total & & 32 & 134 & & \\
\hline
\end{tabular}

Tabel 4.11: Scholarship Indicator

\begin{tabular}{|c|c|c|c|c|c|c|c|}
\hline \multirow{2}{*}{ No } & \multirow{2}{*}{$\begin{array}{l}\text { Ship Crew Performance Variable } \\
\text { (Y) }\end{array}$} & \multicolumn{5}{|c|}{ Respondent Answer } & \multirow[t]{2}{*}{ Total } \\
\hline & & SS & S & RG & $\begin{array}{l}\mathrm{T} \\
\mathrm{S}\end{array}$ & STS & \\
\hline 1 & $\begin{array}{l}\text { Working hour that is not apply by } \\
\text { ship crew is in line with company } \\
\text { rules. }\end{array}$ & 7 & 20 & 5 & 0 & 0 & 32 \\
\hline 2 & $\begin{array}{l}\text { Crew kapal selalu menyelesaikan } \\
\text { pekerjaan tepat waktu. }\end{array}$ & 12 & 14 & 6 & 0 & 0 & 32 \\
\hline 3 & $\begin{array}{l}\text { Crew on board finish their work as } \\
\text { per company order. }\end{array}$ & 9 & 18 & 5 & 0 & 0 & 32 \\
\hline 4 & $\begin{array}{l}\text { Crew on board finish their work } \\
\text { on time, accurate and safe. }\end{array}$ & 8 & 17 & 7 & 0 & 0 & 32 \\
\hline 5 & $\begin{array}{l}\text { Having good enthusiast while } \\
\text { working }\end{array}$ & 11 & 13 & 8 & 0 & 0 & 32 \\
\hline 6 & $\begin{array}{l}\text { Work finish within company } \\
\text { demands. }\end{array}$ & 11 & 18 & 3 & 0 & 0 & 32 \\
\hline 7 & Always finish their work on time. & 8 & 18 & 6 & 0 & 0 & 32 \\
\hline 8 & $\begin{array}{l}\text { Patience and careful while doing } \\
\text { job. }\end{array}$ & 10 & 20 & 2 & 0 & 0 & 32 \\
\hline 9 & $\begin{array}{l}\text { Crew on board taking good care for } \\
\text { the company inventory. }\end{array}$ & 10 & 16 & 6 & 0 & 0 & 32 \\
\hline 10 & Always finish their job accurately & 13 & 17 & 2 & 0 & 0 & 32 \\
\hline & Total & 99 & 171 & 50 & 0 & 0 & 320 \\
\hline & Percentage & 31 & 53 & 16 & 0 & 0 & 100 \\
\hline
\end{tabular}

Respondent's Response to Variable Ships Crew Performance (Y) 


\begin{tabular}{cccccc}
\hline Item & Scale & Frequency & Score & Mean & Category \\
\hline The working & SS & 7 & 35 & & \\
hour for the & S & 20 & 80 & & \\
crew on board & RG & 5 & 15 & 4,06 & Good \\
is in line with & TS & - & & & \\
the company & STS & - & & \\
rules. & & & & \\
\hline Total & & 32 & 130 & & \\
\hline
\end{tabular}

Table 4.13: Indicator for work quantity

\begin{tabular}{clcccc}
\hline Item & \multicolumn{1}{c}{ Scale } & Frequency & Score & Mean & Category \\
\hline Ship crew & SS & 12 & 60 & & \\
always & S & 14 & & & \\
completes & RG & 6 & & 4,18 & Good \\
work on & TS & - & & & \\
time & STS & - & & & \\
\hline Total & & 32 & 134 & & \\
\hline
\end{tabular}

Table 4.14: Indicator of Timeliness

\begin{tabular}{llllll}
\hline Item & Scale & Frequency & Score & Mean & Category \\
\hline Crew ship & SS & 9 & 45 & & \\
completes & S & 18 & 82 & & \\
work as & RG & 5 & 15 & 4,4 & Very Good \\
ordered by & TS & - & & & \\
the & STS & - & & & \\
company & & & & & \\
\hline Total & & & & & \\
\hline
\end{tabular}

Table 4.15: Effective Work Indicators

\begin{tabular}{lccccc}
\hline Item & Scale & Frequency & Score & Mean & Category \\
\hline Crew of the & SS & 8 & 40 & & \\
ship completes & S & 17 & 68 & & \\
the job quickly, & RG & 7 & 21 & 4,03 & Good \\
precisely, and & TS & - & - & & \\
safely & STS & - & - & & \\
\hline
\end{tabular}

Table 4.16: Efficient Work

\begin{tabular}{llllll}
\hline Item & Scale & Frequency & Score & Mean & Category \\
\hline
\end{tabular}




\begin{tabular}{cccccc}
\hline Have high & SS & 11 & 55 & & \\
enthusiasm in & S & 13 & 52 & & \\
carrying out & RG & 8 & 24 & 4,09 & Good \\
work. & TS & - & & & \\
& STS & - & & & \\
& & & &
\end{tabular}

Tabel 4.17: Working Quality Indicator

\begin{tabular}{cccccc}
\hline Item & Scale & Frequency & Score & Mean & Category \\
\hline Work is & SS & 11 & 55 & & \\
completed & S & 18 & 72 & & \\
according to & RG & 3 & 9 & 4,25 & Very Good \\
company & TS & - & & & \\
expectations. & STS & - & & & \\
\hline Total & & 32 & 136 & &
\end{tabular}

Table 4.18: Indicators of work success

\begin{tabular}{cccccc}
\hline Item & Scale & Frequency & Score & Mean & Category \\
\hline Always finish & SS & 8 & 40 & & \\
work on time. & S & 18 & 72 & & \\
& RG & 6 & 18 & 4,06 & Good \\
& TS & - & & & \\
\hline Total & STS & - & & & \\
\hline
\end{tabular}

Table 4.19: Indicators according to Work Standards

\begin{tabular}{cccccc}
\hline Item & Scale & Frequency & Score & Mean & Category \\
\hline Patient and & SS & 10 & 50 & & \\
thorough in & S & 20 & 80 & & \\
doing work. & RG & 2 & 6 & 4,25 & Very good \\
& TS & - & & & \\
& STS & - & & & \\
\hline Total & & 32 & 136 & & \\
\hline
\end{tabular}

Table 4.20: Accuracy and Patience Indicators

\begin{tabular}{cccccc}
\hline Item & Scale & Frequency & Score & Mean & Category \\
\hline Ship crew & SS & 10 & 50 & & \\
maintain and & S & 16 & 64 & & \\
maintain the & RG & 6 & 18 & 4,12 & Very Good \\
company's & TS & - & & & \\
inventory & STS & - & & & \\
properly & & & & & \\
\hline
\end{tabular}




\begin{tabular}{|c|c|c|c|c|c|}
\hline Total & & 32 & 132 & & \\
\hline \multicolumn{6}{|c|}{ Table 4.21: Responsibility Indicators } \\
\hline Item & Scale & Frequency & Score & Mean & Category \\
\hline \multirow{5}{*}{$\begin{array}{c}\text { Always solve } \\
\text { the problem at } \\
\text { hand }\end{array}$} & SS & 13 & 65 & & \\
\hline & $\mathrm{S}$ & 17 & 68 & & \\
\hline & $\mathrm{RG}$ & 2 & 6 & 4,3 & Very good \\
\hline & $\mathrm{TS}$ & - & & & \\
\hline & STS & - & & & \\
\hline Total & & 32 & 139 & & \\
\hline
\end{tabular}

Table 4.22: Indicators of Problem Solving

\begin{tabular}{|c|c|c|c|c|}
\hline $\mathrm{X}$ & $\mathrm{Y}$ & X.Y & $\mathrm{X}^{2}$ & $Y^{2}$ \\
\hline 49 & 46 & 2254 & 2401 & 2116 \\
\hline 46 & 41 & 1886 & 2116 & 1681 \\
\hline 43 & 42 & 1806 & 1849 & 1764 \\
\hline 46 & 45 & 2070 & 2116 & 2025 \\
\hline 43 & 42 & 1806 & 1849 & 1764 \\
\hline 45 & 48 & 2160 & 2025 & 2304 \\
\hline 43 & 47 & 2021 & 1849 & 2209 \\
\hline 45 & 46 & 2070 & 2025 & 2116 \\
\hline 42 & 43 & 1806 & 1764 & 1849 \\
\hline 46 & 45 & 2070 & 2116 & 2025 \\
\hline 43 & 42 & 1806 & 1849 & 1764 \\
\hline 44 & 48 & 2112 & 1936 & 2304 \\
\hline 42 & 40 & 1680 & 1764 & 1600 \\
\hline 44 & 48 & 2112 & 1936 & 2304 \\
\hline 43 & 40 & 1720 & 1849 & 1600 \\
\hline 37 & 39 & 1443 & 1369 & 1521 \\
\hline 37 & 43 & 1591 & 1369 & 1849 \\
\hline 35 & 39 & 1365 & 1225 & 1521 \\
\hline 36 & 42 & 1512 & 1296 & 1764 \\
\hline 37 & 38 & 1406 & 1369 & 1444 \\
\hline 35 & 35 & 1225 & 1225 & 1225 \\
\hline 35 & 37 & 1295 & 1225 & 1369 \\
\hline 37 & 41 & 1517 & 1369 & 1681 \\
\hline 38 & 37 & 1406 & 1444 & 1369 \\
\hline 39 & 39 & 1521 & 1521 & 1521 \\
\hline 37 & 39 & 1443 & 1369 & 1521 \\
\hline 34 & 39 & 1326 & 1156 & 1521 \\
\hline
\end{tabular}




\begin{tabular}{ccccc}
\hline 34 & 38 & 1292 & 1156 & 1444 \\
\hline 30 & 40 & 1200 & 900 & 1600 \\
\hline 36 & 40 & 1440 & 1296 & 1600 \\
\hline 33 & 40 & 1320 & 1089 & 1600 \\
\hline 33 & 40 & 1320 & 1089 & 1600 \\
\hline 1267 & 1329 & 53001 & 50911 & 55575
\end{tabular}

Tabulation of the $\mathrm{X}$ and Y Corellation Coefficient

\subsection{Analysis of The Correlation Coeffisient}

To find out how the relationship of compensation to performance is carried out a correlation analysis test. Based on research data obtained from respondents, then if applied in the formula, the following results will be obtained:
$\mathrm{N}=32$
$\sum \mathrm{X}=1.267$
$\sum X Y=53.001$
$\sum \mathrm{Y}=1.329$
$\sum X^{2}=50.911$
$\sum \mathrm{Y}^{2}=55.575$

The overall results are included in the product moment correlation formula, so the results can be seen as follows:

$$
\begin{aligned}
& \mathbf{r}=\frac{\boldsymbol{n}\left(\sum X Y\right)-\left(\sum X\right)\left(\sum Y\right)}{\sqrt{\left(\boldsymbol{n}\left(\sum X^{2}\right)-\left(\sum X\right)^{2}\right)\left(\boldsymbol{n}\left(\sum Y^{2}-\left(\sum Y\right)^{2}\right)\right.}} \\
& r=\frac{(32)(53.001)-(1.267)(1.329)}{\sqrt{\left((32)(50.911)-(1.267)^{2}\right)\left((32)(55.575)-(1.329)^{2}\right)}} \\
& r=\frac{1.021 .008-1.014 .000}{\sqrt{(1.010 .976-1.000 .000)(1.036 .032-1.028 .196)}} \\
& r=\frac{7.008}{\sqrt{(10.976)(7.836)}} \\
& r=\frac{7.008}{\sqrt{86.007 .936}} \\
& r=\frac{7.008}{9.274,0463660691} \\
& r=0,755
\end{aligned}
$$

From the results of the calculation above, it can be seen that the value of $r=0.755$ means that compensation has a strong relationship with the crew's performance and is positive, meaning that if compensation is increased the performance will increase. 


\subsection{Simple Linear Regression Analysis}

To find out the relationship between compensation (variable $\mathrm{x}$ ) and performance ( $\mathrm{y}$ variable) a simple linear regression analysis will be carried out using the formula:

$$
Y=a+b X
$$

Where to find out the value of $a$ and $b$ used by the formula:

$$
\begin{gathered}
a=\frac{\sum y-b \sum x}{n} \\
b=\frac{n \cdot \sum x y-\sum x \cdot \sum y}{n \cdot \sum x^{2}-\left(\sum x\right)^{2}}
\end{gathered}
$$

Where to find out the value of $\mathrm{a}$ and $\mathrm{b}$ used by the formula:

$$
\begin{aligned}
& \boldsymbol{b}=\frac{\boldsymbol{n} \cdot \sum \boldsymbol{x} \boldsymbol{y}-\sum \boldsymbol{x} \cdot \sum \boldsymbol{y}}{\boldsymbol{n} \cdot \sum \boldsymbol{x}^{2}-\left(\sum \boldsymbol{x}\right)^{2}} \\
& b=\frac{(32)(53.001)-(1.267)(1.329)}{(32)(50.911)-(1.267)^{2}} \\
& b=\frac{(32)(53.001)-(1.267)(1.329)}{(32)(50.911)-(1.000 .000)} \\
& b=\frac{(1.021 .008)-(1.014 .000)}{(1.010 .976)-(1.000 .000)} \\
& b=\frac{7.008}{10.976} \\
& b=0,638483965 \\
& b=0,64 \\
& \boldsymbol{a}=\frac{\sum \boldsymbol{y}-\boldsymbol{b} \sum \boldsymbol{x}}{\boldsymbol{n}} \\
& a=\frac{1.329-(0,638483965)(1.267)}{32} \\
& a=\frac{1.329-638,483965}{32} \\
& a=\frac{375,516035}{32} \\
& a=11,734876
\end{aligned}
$$


$a=11,73$

Then the results will be obtained as follows:

The results of the simple regression coefficient calculation above show the coefficient value of the independent variable compensation (a) is equal to 11.73. And the dependent variable coefficient of ship crew performance (b) is 0.64 . So that the regression equation is obtained as follows:

$$
\begin{gathered}
Y=a+b X \\
Y=11,73+0,64 X
\end{gathered}
$$

Based on the above equation it is known that the coefficient value (b) is 0.64 . Mathematically, this coefficient value states that when compensation 0 , the crew's crew performance has a value of 0.64. Furthermore, the value (11.73) in the independent variable regression coefficient (compensation) illustrates that the direction of the relationship between the independent variable (compensation) and the dependent variable (ship crew performance) is unidirectional, where each increase in one compensation variable unit will cause an increase in crew performance the ship is 11,73 .

\subsection{Analysis of the Determining Coefficient (Coefficient Of Determination)}

To measure the size of the contribution of variable $\mathrm{X}$ to the ups and downs of the $\mathrm{Y}$ variable can be searched by the formula:

$K P=r^{2} \times 100 \%$

$K P=0,755^{2} \times 100 \%$

$K P=0,570025 \times 100 \%$

$K P=57,0025 \%$

$K P=57,00 \%$

The results of the above calculations explain the magnitude of the correlation value or relationship (R) which is equal to 0.755 and explained the percentage of the influence of independent variables on the dependent variable called the coefficient of determination which is the result of the $\mathrm{R}$ calculation. which implies that the influence of independent variables (compensation) on the dependent variable (performance) is $57.00 \%$, while the remaining $43.00 \%$ is influenced by other factors, which are not examined by the author.

\section{Discussion}

This study seeks to obtain an overview of the effect of compensation on the performance of the Floating Crane Ratu Giok-2 ship crew owned by PT. KartikaSamudraAdijaya. After analyzing the problems found, the compensation variable affects the crew's crew performance, evidenced by data analysis using predetermined research methods. From the test results, the discussion is as follows:

\subsection{Discussion of Compensation Variables}

The results of the calculation of the average score on each indicator in the questionnaire item that has been distributed to the respondents the crew of the Floating Crane Ratu Giok-2 obtained the lowest score, that is the basic salary indicator with a score of 3.4. From this calculation 
shows that the ship's crew feels that the basic salary given by the company is not sufficient for the crew's needs. This is relevant to the problems listed in CHAPTER I, namely compensation received by ship crew under the UMR standard.

\subsection{Discussion of Ship Crew Performance Variables}

The results of the calculation of the average score on each indicator in the questionnaire item that has been distributed to the respondents the crew of the Floating Crane Ratu Giok- 2 obtained the lowest score, that is the efficient work indicator with a score of 4.03. From this calculation shows that the ship crew feels that they have not fully carried out the work quickly, precisely, and safely. This is relevant to the problems listed in CHAPTER I, which are ship crews who don't carry out work discipline and don't use work safety equipment.

\subsection{Problem Solving}

Problem solving is a solution used at the end of a study. In some cases, parties involved in this problem may also be able to carry out trials with the best problem solving by trying one of the most effective alternatives to improve the performance of the Floating Crane Ratu Giok-2 crew owned by PT. Kartika Samudra Adijaya. In general, decision making will use knowledge, considerations, and experience to determine which alternatives are best used to solve problems. The following are the results of the solution to the results of the research:

Variable $\mathrm{X}$ is compensation for which the calculation results have the lowest average score of 3.4, namely the indicator of basic salary. This means that the basic salary is the most dominant indicator among other indicators that have the lowest score. The basic salary is a reward in the form of cash received by the crew of the ship every month when they are on board. The company must increase the basic salary given to the crew of the ship by considering a lot of things because from the results of the research, the calculation shows that this indicator is felt by the crew of the ship has not met and must be improved. By increasing this indicator, the ship's crew will remain enthusiastic and motivated high in work so that it will cause an increase in the performance of the ship's crew.

Variable $\mathrm{Y}$ is the crew performance of the ship whose calculation results have the lowest average score of 4.03 which is a work efficient indicator. This means that work is the most dominant indicator among other indicators that have the lowest score. Efficient work is a picture of the workings of ship crews who carry out their work quickly, precisely, and safely. The company must improve the ship's crew work efficiently because from the results of the research, the calculation shows that this indicator is felt by the crew of the ship not fulfilling and must be improved. By improving this indicator, the problems regarding work time discipline and the use of work safety equipment on ship crews can be further improved by monitoring the workings of ship crews by giving standard ship crew work and giving sanctions if the ship's crew does not comply with company instructions.

\section{Conclusion}

The analysis of the author did regarding the effect of compensation on the performance of the Floating Crane Ratu Giok-2 crew owned by PT. Kartika Samudra Adijaya, then at the end of this writing the author tries to give conclusions which include the following:

The results of data analysis regarding the lowest indicator for the compensation variable are indicators of basic salary. Based on the problems found in CHAPTER I, namely compensation 
below the UMR standard. This is relevant to the results of data analysis that produces indicators with the lowest value from the results of questionnaires filled out by respondents, namely indicators of basic salary. So the problems in CHAPTER I are answered by the results of the analysis.

The results of data analysis regarding the lowest indicator for the ship crew performance variable are efficient work indicators which means that it is related to the workings of the ship crew who carry out their duties quickly, precisely and safely. Based on the problems found in CHAPTER I, the ship crew's performance is low, work time discipline is not good and the utilization of work safety equipment is low. This is relevant to the results of data analysis that produces indicators with the lowest value from the results of questionnaires filled out by respondents, namely efficient work indicators. So the problems in CHAPTER I are answered by the results of the analysis. Furthermore, the results of the numbers obtained in the determinant coefficient analysis, which is equal to $57.00 \%$, means that the contribution or effect of compensation on ship crew performance is $57.00 \%$ and the remaining $43.00 \%$ is influenced by other factors, such as education, discipline, health, and motivation.

\section{Suggestions}

Based on the discussion that the author has stated, then in this last chapter the author will provide suggestions as follows:

The company should determine the salary of the ship's crew above the UMR of the city where the company is located, taking into account all aspects that adjust the company's finances. Because if the salary is adjusted to the UMR, the crew will have a higher working spirit so that they are expected to improve the performance of the crew.

The company should establish a system to monitor the performance of the ship's crew by making a checklist of the suitability of the company's work standards on board. If there are crew members who do not comply with company instructions, they must be sanctioned in the form of cutting salaries or cutting off time. So that it will motivate the ship's crew to work according to the standards provided by the company.

\section{References}

[1] S. Edy, Manajemen sumber daya Manusia. Jakarta: Kencana, 2009.

[2] M. S. P. Hasibuan, Manajemen Sumberdaya Manusia. Jakarta: PT. Bumi Aksara, 2003.

[3] T. Hani Handoko, Manajemen Personalia \& Manajemen Sumber Daya Manusia. Yogyakarta: BPFE-Yogyakarta, 1987.

[4] H. Nawawi, Evaluasi dan manajemen kinerja di lingkungan perusahaan dan industri. Yogyakarta: Gadjah Mada University Press, 2006.

[5] J. Simanjuntak Payaman, Manajemen dan Evaluasi Kinerja. Jakarta: Lembaga Penerbit Fakultas Ekonomi Universitas Indonesia, 2005. 